\title{
Malignant Islet-Cell Tumors of the Pancreas
}

\author{
Norman W. Thompson, M.D., and Frederic E. Eckhauser, M.D. \\ Surgical Services, Ann Arbor Veterans Administration Hospital and Division of Endocrine Surgery and Department of Surgery, The \\ University of Michigan Hospitals, Ann Arbor, Michigan, U.S.A.
}

\begin{abstract}
Although malignant islet-cell tumors are uncommon, they are an important group of pancreatic neoplasms because appropriate treatment can often result in effective palliation even though cure is infrequent. In general, these tumors are relatively slow growing so that a combination of surgical and chemotherapeutic measures may prove very beneficial. In some patients with tumors hypersecreting insulin, gastrin, glucagon, or vasoactive intestinal polypeptide (VIP), the hormonal effects of the neoplasm can be life-threatening. Surgical treatment must, therefore, consider both the functional and malignant characteristics of the individual tumor. In many patients with functional tumors, surgical debulking of the primary tumor may be indicated even when a curative resection cannot be accomplished. Some malignancies may be cured by an appropriate pancreatic resection even when peripancreatic lymph nodes are already involved. Although a Whipple procedure is not indicated when hepatic metastases are present, this procedure may cure tumors localized to the pancreatic head and/or peripancreatic lymph nodes. Because hepatic metastases are usually multiple and involve both lobes, liver resections, other than wedge excisions of peripherally located functional metastases, are not indicated. Malignant nonfunctioning islet-cell tumors are probably best treated with systemic or regional chemotherapy when metastatic. Surgical resections or bypass procedures may be infrequently useful in those cases in which the primary tumor causes either duodenal or bile duct obstruction: The most effective methods used to control hepatic metastases are systemic and hepatic arterial chemotherapy. An alternative is selective hepatic artery embolization. Recently, an implantable hepatic arterial infusion pump has been used with encouraging results in this group of patients. The
\end{abstract}

Reprint requests: Norman W. Thompson, M.D., Division of Endocrine Surgery, The University of Michigan Hospitals, D2227 South Ambulatory Care Building, Ann Arbor, Michigan 48109-0010, U.S.A. chemotherapeutic agents that have been most effective in the treatment of hepatic metastases include streptozotocin, DTIC, and fluorouracil.

Since the diagnosis and surgical treatment of an islet-cell tumor causing hypoglycemia in 1926 and the description of the Zollinger-Ellison syndrome in 1955, there has been an ever-increasing interest in islet-cell tumors, their secretions, and their biological behavior [1]. Other tumor syndromes have been defined including the Verner-Morrison or watery diarrhea syndrome in 1958 and the glucagonoma syndrome in 1966 [2, 3]. Islet-cell tumors secreting pancreatic polypeptide, somatostatin, ACTH, calcitonin, and serotonin have also been identified through clinical and immunohistochemical studies of specimens excised at operations or autopsies [4, 5]. It is estimated that $10-15 \%$ of all islet-cell tumors are nonfunctional or at least secrete no hormone that is detectable by available immunoassays. Despite the variety of different clinical syndromes caused by these tumors, their biological behavior is generally similar in that they are usually slow growing. When malignant, they usually metastasize to the regional lymph nodes and to the liver. Their response to radiation and chemotherapy is also predictably similar. All islet-cell tumors, regardless of function, may arise sporadically or occur as a component of the MEN I syndrome. However, there are important differences in the incidence of malignancy, effects of hormone secretion, and response to therapy that are important clinically (Table 1). In this report, malignant islet-cell carcinomas will be considered in relationship to their functional syndromes and their occurrence sporadically and in the MEN I syndrome. Therapeutic emphasis will 
Table 1. Islet-cell tumors: incidence of metastases at time of diagnosis.

\begin{tabular}{ll}
\hline Insulinomas & $10-15 \%$ \\
Gastrinomas & $60-70 \%$ \\
Glucagonoma & $60-70 \%$ \\
VIPomas & $50 \%$ \\
Somatostatinoma & $50 \%$ \\
PPomas & $50 \%$ \\
\hline
\end{tabular}

stress both antihormonal and antitumor management.

\section{Insulinomas}

Insulinomas have been considered the most common islet-cell tumor, with nearly 3,000 cases reported since 1926. Most insulinomas are benign and can be cured by enucleation or partial pancreatectomy. In most series, only 5-10\% are malignant as determined by local invasion and lymph node, liver, or systemic metastases. In a 1950 collected review of 398 cases, it was found that $37(9.3 \%)$ were malignant [6]. Stefanini et al. [7, 8], in their 1974 review of 1,067 cases, found that $15 \%$ were malignant with about one-third having metastasized at the time of initial diagnosis. Malignancy was demonstrated in $11 \%$ of insulinomas at the Mayo Clinic as determined by lymphatic or hepatic metastases or by perineural and/or vascular invasion [6].

Since 1960 we have treated 69 patients with proven hyperinsulinism at the University of Michigan [9]. Four of these patients $(6 \%)$ were proven to have malignant insulinomas as determined by metastases to either lymph nodes or liver. Two additional patients, of whom one was an MEN I patient, had locally invasive tumor involving pancreatic tissue but were cured by resection. If these 2 patients are included as malignant insulinomas, $8.6 \%$ of our total insulinoma population had malignant islet-cell tumors. Islet-cell malignancies causing hyperinsulinism and hypoglycemia were sporadic in 4 patients and familial in 2 , occurring in association with the MEN I syndrome. Three patients with sporadic malignant insulinomas had liver metastases at the time of diagnosis. One of the MEN I patients had multicentric islet-cell carcinoma with regional lymph node involvement. Surprisingly, his symptoms were relatively mild. Hypoglycemic symptoms could not be elicited by a standard 72-hour fast. His maximum insulin level was $15 \mu \mathrm{U} / \mathrm{ml}$, a value that is much lower than that found in most patients with symptomatic malignant insulinomas. At operation, it was possible to do en bloc resection of his distal pancreas along with regional lymph nodes. A second islet-cell tumor was enucleated from the head of the pancreas. The peripancreatic lymph nodes contained metastatic islet-cell carcinoma, but the patient has done well during a 15-year period of follow-up. The other MEN I patient, a 40-year-old woman, underwent resection of the distal body and tail of the pancreas. Two small tumors were found and one contiguous lymph node was found to contain islet-cell tumor. She, too, has remained symptom free for a period of follow-up of 10 years. It is noteworthy that of all patients with insulinomas, only $4 \%$ have the MEN I syndrome [1]. This low incidence of the MEN I syndrome in patients with insulinoma contrasts with the $30-40 \%$ incidence of parathyroid and pituitary disease in patients with gastrinomas [4, 10-14]. In addition to the 3 patients with sporadic insulinomas and liver metastases, a 55-year-old patient was found to have a locally invasive tumor in the tail of his pancreas. He was treated by resection when it became apparent that enucleation was not feasible. Following that operation, he has done well for a 5-year period without evidence of recurrence.

The symptoms of malignant insulinoma are similar to those in patients with benign adenomas or diffuse islet-cell hyperplasia. They consist of neuroglucopenic symptoms as well as symptoms due to adrenergic stimulation. In patients with malignant islet-cell tumors, the onset of symptoms may be more acute and rapidly progressive than in patients with benign disease. As noted above, nearly all patients with proven malignancy have lymph and/or liver metastases. Whether local invasion without lymph node involvement is sufficient evidence to classify these tumors as malignant is not clear. In our experience, patients with tumors having invaded locally into surrounding pancreatic parenchyma have done well after resection without evidence of tumor recurrence.

The biochemical diagnosis of hyperinsulinism is made on the basis of fasting hyperglycemia and the determination of immunoreactive insulin-to-glucose ratios. If this ratio is greater than 0.3 , the diagnosis can usually be made within the first 24 hours of a 72-hour fast. Of our total insulinoma patients, nearly $90 \%$ could be diagnosed within the first 24 hours $[9,15]$. The only exception was a malignant insulinoma occurring in the MEN I patient discussed earlier. It should be emphasized that absolute increases in insulin levels are not found in all patients with proven tumors, primarily because of the sporadic secretion of insulin by the tumor. The C-peptide level is a valuable adjunctive biochemical study in borderline patients because of its longer plasma half-life. It is particularly useful when the insulin levels are normal in a hypoglycemic patient who is suspected of having an insulinoma. When the levels of insulin are elevated in association with 
hypoglycemia, the diagnosis can be made with assurance. The normal level of fasting insulin in our laboratory is $20 \mu \mathrm{U} / \mathrm{ml}$. The insulin levels in 51 patients with insulinomas proven at operation ranged from 11 to $179 \mu \mathrm{U} / \mathrm{ml}$ when the patients were hypoglycemic. Three patients with sporadic islet-cell malignancies had insulin levels of 59, 64, and $1,260 \mu \mathrm{U} / \mathrm{ml}$, respectively. The extremely high level seen in the third patient suggests the presence of malignancy. However, levels in the first two patients with hepatic metastases were similar to those seen in patients with benign disease.

Pro-insulin values may help to confirm the diagnosis of malignant insulinoma [2]. Normally this hormone comprises 10-15\% of total insulin and rarely constitutes more than $22 \%$ of the total immunoreactive insulin (IRI) in normal patients. Insulin-secreting neoplasms typically release excessive amounts of pro-insulin into the circulation. Therefore, estimation of the percentage of proinsulin to insulin may be helpful in predicting the possibility of malignancy, especially when it exceeds $40 \%$. Since 1960, the pro-insulin component exceeded $22 \%$ of the total fasting IRI in more than $80 \%$ of patients with proven tumors [9]. In patients with islet-cell carcinomas, an even higher proportion is usually found in the plasma. However, in any individual patient, the percentage of pro-insulin compared to the total IRI may not accurately differentiate malignant from benign insulinomas.

Another biochemical study that may be helpful in identifying patients with malignant insulinomas is human chorionic gonadotropic (hCG) hormone level. Increased plasma levels of the alpha and beta fractions of hCG have been found in patients with malignant islet-cell tumors. These fractions have not been elevated in any of the 41 benign insulinomas studied so far [9]. When levels of this hormone are elevated, the diagnosis of islet-cell malignancy becomes likely, but a normal level does not rule out malignancy. Other studies that can be used in the preoperative assessment of insulinoma patients include technetium liver scans which will identify cold areas consistent with liver metastases, pan visceral arteriography which will demonstrate hypervascular liver densities as small as $1.5 \mathrm{~cm}$, and computed tomography (CT) scans with contrast enhancement. Unfortunately, many patients with metastatic insulinomas have very small metastases and these studies may all be negative. Selective portal venous sampling can be useful to localize a single source of pancreatic insulin hypersecretion or to demonstrate diffuse islet-cell hypersecretion. Portal venous samples can also help to identify liver metastases especially when compared to simultaneously drawn hepatic venous samples [16]. The ratio of hepatic to portal vein insulin is affected by hepatic insulin extraction and must, therefore, be interpreted with caution.

Diazoxide testing is done in all patients with proven hyperinsulinism. This study, which should be performed prior to any other definitive treatment, may help to determine suppression sensitivity of tumor or hyperplastic islet tissue. Diazoxide should be given with a natriuretic diuretic in order to eliminate the salt-retaining effects of diazoxide. Hirsuitism is another side effect of diazoxide which can occur when the drug is administered long-term.

Malignant islet-cell tumors that produce insulin can be treated by antihormonal therapy and/or antitumor therapy when surgical cure cannot be attained. It is clear that the development of diazoxide (Proglycem ${ }^{\mathbb{B}}$ ) represents a major therapeutic advance $[9,15]$. This drug directly inhibits release of insulin by the beta cells of the pancreas. The mechanism embodies stimulation of alpha adrenergic receptors with inhibition of cyclic AMP phosphodyesterase. The latter effect results in high plasma levels of cyclic AMP which in turn enhances glycogenolysis. The dose varies from 150 to 450 mg/day. Several other drugs may prove useful to inhibit insulin release including Inderal ${ }^{\circledR}$, chlorpromazine, and cortisone.

The single most important antitumor drug available today for treating malignant insulinomas is streptozotocin $[6,15,17,18]$. This drug is a broadspectrum antibiotic and a naturally occurring nitrosourea that causes selective destruction of the pancreatic beta cell. It is effective in controlling hypoglycemia and usually results in a measurable decrease in tumor size. Objective reduction in tumor mass has been noted in approximately $50 \%$ of patients treated with streptozotocin for functioning malignant insulinomas but less than $20 \%$ of patients have a complete remission. Moreover, despite a favorable biochemical response in approximately $25 \%$ of patients, treatment has not been shown to prolong survival significantly. Streptozotocin toxicity can affect the kidney, liver, and bone marrow. Renal tubular toxicity is the most serious complication of the drug and limits the amount that can be administered. This complication can be avoided by monitering daily urinary protein losses. A weekly schedule of $0.5-2 \mathrm{~g} / \mathrm{m}^{2}$ administered intravenously has been used most frequently. Streptozotocin can also be used with fluorouracil and both are given intravenously. This combination therapy has achieved an overall response rate of $63 \%$ and a complete response rate of $33 \%$ in patients with advanced islet-cell carcinoma [18].

Two other drugs have been used with some success to treat malignant insulinomas. Mithromycin causes a sharp decline in plasma insulin levels after small intravenous doses. In 1 reported patient, 
four 1-mg doses were followed by euglycemia for 2 weeks and no symptoms of hypoglycemia for another 8 weeks [19]. This particular patient later died of unrelated disease. Adriamycin ${ }^{(B)}$ has also been used occasionally to reduce insulin levels and in 2 patients, led to remissions of 5 and 7 months, respectively [9]. Cardiac toxicity and bone marrow suppression are the principal side effects of Adriamycin ${ }^{\circledR}$ therapy.

The surgical treatment of malignant insulinomas is resection whenever possible $[1,4,6,8]$. Locally invasive tumors in the body and tail can usually be excised along with peripancreatic lymph nodes. A Whipple resection may be indicated when a tumor in the head of the pancreas is locally invasive and the patient has no liver metastases. When there is evidence of surgical incurability because of distant metastases, every effort should be made to debulk as much primary and secondary tumor as possible. Reducing the mass of functional tissue may offer significant palliation and decrease the doses of chemotherapy necessary to control the patient's symptoms [8].

\section{Gastrinomas}

The Zollinger-Ellison syndrome (ZES) was originally characterized by intractable peptic ulcer disease, multiple or jejunal ulcers, and a non-beta islet-cell malignant tumor (gastrinoma) with liver metastases [14]. Subsequent to the original report in 1955, great interest in this fascinating syndrome rapidly developed. With clinical awareness and the availability of an assay for gastrin, diagnosis of this disease became more frequent and occurred at an earlier stage than in patients seen before 1970. After a decade of clinical experience with the ZES, it was estimated that more than $60 \%$ of gastrinomas were malignant with metastases to lymph nodes and/or the liver at the time of diagnosis $[10-12,14]$. The standard treatment for the disease became total gastrectomy. Thus, surgical treatment of the ZES was initially directed at the target organ. No direct attempt was made to cure the islet-cell neoplasm. It was soon learned that any operation that spared even a small portion of stomach might lead to unremitting peptic ulcer disease. At first, surgeons made no attempt to resect the pancreatic islet-cell disease even when no metastases were apparent at operation. In a few cases, however, cures were reported after resection of either a duodenal or pancreatic gastrinoma that was apparently benign. It later became apparent that, although many malignant gastrinomas are very slow growing, eventually long-term survivors of total gastrectomy will be likely to die from liver metastases [10-12, 14]. In some cases this occurred inexorably within a few years, while in others the course was slowly progressive. Surprisingly, a small group of patients showed regression of liver metastases after total gastrectomy, prompting Friesen to speculate that a gastric factor might be necessary in some cases to promote tumor growth $[4,12]$.

During the past decade, a number of events have occurred that led to re-evaluation of the management of the ZES. Perhaps most important was the introduction of potent $\mathrm{H}_{2}$-blocking drugs which effectively inhibit the effects of gastrin on the parietal cell. For the first time these drugs achieved some measure of control of the severe ulcer diathesis in most patients with the ZES. This made performance of elective surgical procedures in ZES patients possible. Furthermore, total gastrectomy was no longer mandatory, particularly if good drug control had been demonstrated preoperatively $[13$, 20-22]. Because of the high incidence of malignancy, some authors advocated no other treatment other than $\mathrm{H}_{2}$-blockers, claiming that total gastrectomy was meddlesome and that attempts at surgical cure were futile.

The second major advance in managing ZES was the development of sensitive radioimmunoassay for gastrin and a provocative study (secretin stimulation) to prove that elevated gastrin levels were due to the presence of a gastrinoma $[4,12,22,23]$. This allowed for more precise diagnosis at an earlier stage than had ever before been achieved. As a result of these advances, many patients who had been diagnosed with rather typical peptic ulcer disease after short histories turned out to have early forms of ZES. These patients usually present with intermittent or persistent diarrhea. Other patients with ZES that are now being diagnosed before clinical symptoms become severe are those with MEN I syndrome. These patients all have asymptomatic hyperparathyroidism [5]. Regular screening has detected hypergastrinemia in this group as well as in MEN I patients who have been symptomatic.

The last development to influence the surgical treatment of the ZES is the development of percutaneous transhepatic selective pancreatic venous sampling which allows for precise localization of the source or sources of hypergastrinemia. When this procedure is combined with hepatic venous sampling, it is possible to predict the presence or absence of hepatic metastases [24]. In conjunction with selective arteriography and CT scanning of the liver, our ability to define the extent of disease has been vastly improved. The application of these advances has caused a gradual evolution in the philosophy of the treatment of the ZE syndrome.

The goal of management today is to identify those ZES patients who have localized tumors of the pancreas or the duodenum that have not metasta- 


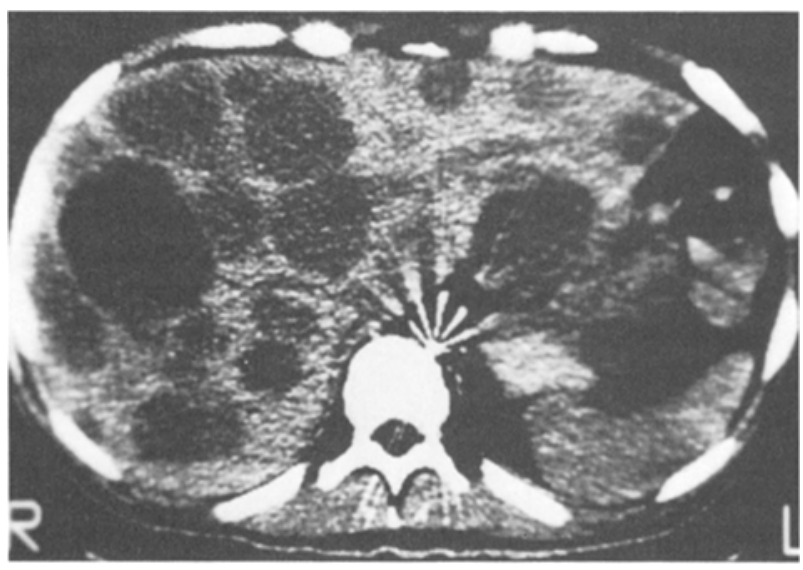

Fig. 1. Computed tomographic (CT) scan of liver demonstrating multiple metastases from islet-cell carcinoma of the pancreas in 54-year-old man.

sized. Surgical therapy is directed at the primary disease whenever possible. It has become increasingly clear that some patients, particularly those with sporadic gastrinomas, are curable. Total gastrectomy or any other ulcer procedure can be avoided in this group. It is estimated that at least $20 \%$ of ZES patients are candidates for a curative procedure. This may, howver, require a partial pancreatic resection. In some cases, enucleation of the tumor may suffice. We have recently identified 3 patients who were candidates for local tumor resection; the pancreas and stomach were left intact [24]. These patients are free of symptoms and have normal basal and secretin-stimulated gastrin levels. Selective pancreatic and hepatic venous hormone sampling was used successfully to identify these ZES patients prior to operation.

Once the diagnosis of hypergastrinemia due to a sporadic gastrinoma has been firmly established, selective visceral arteriography is used for possible identification of the primary tumor and/or liver metastases. Many gastrinomas and small hepatic metastases will not be demonstrated by this technique and other localization studies are indicated. CT scanning will show most primary tumors larger than $2 \mathrm{~cm}$ as well as hepatic metastases larger than $1.5 \mathrm{~cm}$ (Fig. 1). If there is no evidence of metastatic gastrinoma with these techniques, selective pancreatic and hepatic venous gastrin sampling is performed. If this study shows gastrin secretion from a localized pancreatic or duodenal source, it may be possible to cure the patient. Nevertheless, at exploratory celiotomy, the liver and peripancreatic lymph nodes should be carefully evaluated. When the preoperative evaluation has demonstrated metastatic disease or metastases are found at operation, the surgical treatment of malignant ZES is individualized. In most younger and good-risk older pa- tients, total gastrectomy may still be the procedure of choice. In addition, an attempt to resect the gastrinoma and its metastases should be considered in selected cases. As an example, in the recent case of a 17-year-old male, we performed a left lateral hepatic segmentectomy for a large single metastasis in addition to a total gastrectomy and distal pancreatectomy. Surprisingly, his serum gastrin levels have remained normal for a 1-year period. Until recently, we usually performed a total gastrectomy even when only a single lymph node was found to be involved with metastases and the liver was normal to palpation. However, we now have accumulated a group of 7 ZES patients whose only evidence of disease was a single lymph node. They have shown no recurrence over an extended period of time and continue to have normal basal serum gastrin levels which do not respond to secretin administration. Four of these patients had concomitant total gastrectomies which may not have been necessary. The majority of patients with metastatic peripancreatic lymph nodes have palpable pancreatic tumors. Our current policy is to resect the tumor and involved lymph nodes. We now wait for the results of follow-up gastrin testing before making a decision for or against total gastrectomy.

Patients with extensive hepatic metastases are candidates for chemotherapy. Some patients have shown a good response to streptozotocin and/or 5-fluorouracil (5-FU). When systemic chemotherapy is effective and well-tolerated, it may be used intermittently on a long-term basis. In the patients failing to respond or to tolerate systemic chemotherapy, we are currently using an implantable pump for hepatic artery chemotherapy infusion. The early results with this technique have been encouraging.

Patients with ZES as a component of the MEN I syndrome comprise more than a third of the total population of ZES patients. The ZES patients can be identified by their family history or the presence of concomitant hyperparathyroidism. Their distinctive pancreatic disease merits special emphasis.

Using histological and immunohistochemical techniques, we have recently examined the tumors and nontumorous pancreata from 14 patients with the MEN I syndrome [5]. We found diffuse disease of the islet cells characterized by nesidioblastosis, hyperplasia, and microadenomatosis in all and multiple tumors in most. This evidence of diffuse isletcell disease suggests that pancreatic operations less than total pancreatectomy are unlikely to cure hypergastrinemia in most MEN I patients.

During the past 5 years, all MEN I patients with ZES had pancreatic venous hormone sampling [24]. Most of these patients have had multiple or diffuse sources of gastrin secretion from the pancreas or 
duodenum. However, in 4 patients, localized gastrin secretion was found and, at operation, pancreatic tumors were enucleated and distal pancreatectomies were performed. These patients are not cured but each has been asymptomatic without the need for gastrectomy or cimetidine during a followup period ranging from 1 to 4 years. All 4 have elevated serum gastrin levels when stimulated with secretin and basal levels at the upper limits of normal. We anticipate that these patients may eventually require further medical or surgical therapy.

A total pancreatectomy is the only procedure that may be curative in the MEN I patient with no evidence of metastatic gastrinoma. Nevertheless, this operation is not recommended in the treatment of ZES. The benefits of this operation are outweighed by the operative mortality rate and longterm morbidity of insulin-dependent diabetes. Furthermore, after either total pancreatectomy or a Whipple resection for ZES, previously occult liver metastases may appear. A total gastrectomy in addition to a total pancreatectomy is contraindicated because the combined procedures are poorly tolerated.

The malignant potential of small islet-cell tumors in the MEN I patients should not be ignored, however. Their early detection and excision may prevent tumor-related deaths. We recommend distal pancreatectomy with enucleation of other functional and "silent" tumors found in the pancreatic head in potentially curable patients. Our longterm follow-up of all MEN I patients includes periodic CT examination of the remaining pancreatic head and reassessment of gastrointestinal-pancreatic hormone levels at 1-year intervals.

\section{Glucagonomas}

The first well-documented patient with a glucagonsecreting tumor was described by McGavran and associates in 1966 [2]. However, the syndrome was not widely recognized until Mallison et al. reported 9 patients with common findings in 1974 [25]. These authors described the clinical features of the syndrome, including: (a) a characteristic dermatitis (necrolytic migratory erythema); (b) diabetes mellitus; (c) a normochromic, normocytic anemia; (d) weight loss; (e) glossitis; (f) hypoaminoacidemia; (g) elevated blood glucagon levels; and (h) alpha-cell tumor of the pancreas. Most patients are malnourished at the time of diagnosis. Significant weight loss has occurred because of the catabolic effects of glucagon. Despite normal coagulation studies, these patients also have a high incidence of venous thrombosis. Pulmonary emboli are common and have been reported even in patients on anticoagulation therapy.
In most cases, the glucagonoma syndrome occurs as a late manifestation of the disease. The majority of patients already have metastatic disease and are unlikely to be cured by surgical resection. In a collective review of the 45 patients reported through 1978, Higgins found that two-thirds of the patients were incurable at the time of their initial exploration [26].

Localized tumors are treated by pancreatic resection. A Whipple resection is indicated for large tumors in the head of the pancreas. This may be justified even when metastases are present in order to alleviate the debilitating effects of excess glucagon. An alternative operation in some patients is a subtotal $(95 \%)$ pancreatectomy. An aggressive surgical approach is indicated because the catabolic effects of glucagon may be palliated by debulking the tumor followed by chemotherapy. One of our patients with a $10-\mathrm{cm}$ tumor in the head of the pancreas was treated by $95 \%$ pancreatectomy even though 2 small hepatic metastases were present. The effects of hormone excess may be more lifethreatening to patients with functional endocrine tumors such as glucagonomas, insulinomas, and vasoactive intestinal polypeptideomas (VIPomas) than the islet-cell malignancy itself. To remove locally invasive tumors, it may be necessary to resect a portion of the superior mesenteric vein. A technique we have used to reconstruct the superior mesenteric vein is depicted in Fig. 2A-C. Anastomosis of the splenic vein stump to the caudal end of the superior mesenteric vein restores mesenteric venous inflow to the liver. Even in patients with liver metastases, resection of the tumor can result in rapid resolution of the dermatitis within 48 hours. Similar results have been reported by others after palliative procedures for glucagonomas [4, 23, 25, 26].

Because of the long-standing, debilitating cachexia, patients with glucagonomas should be prepared preoperatively with hyperalimentation. Antibiotic therapy is indicated in patients with severe skin infections. Steroid therapy may be used preoperatively, on a short-term basis, if the skin rash is severe. Low doses of insulin may be required to control the diabetes caused by the hyperglucagonemia. The high risk of venous thrombosis must be considered [25]. These patients should be well-hydrated, and treated with low doses of heparin before and after operation and provided with elastic support stockings.

The majority of patients with sporadic glucagonomas are candidates for chemotherapy after debulking operations because of unresectable metastases $[4,26]$. While liver metastases should be treated generally by wedge resection, several other techniques may be considered. Selective hepatic arterial ligation has been used by some with limited suc- 

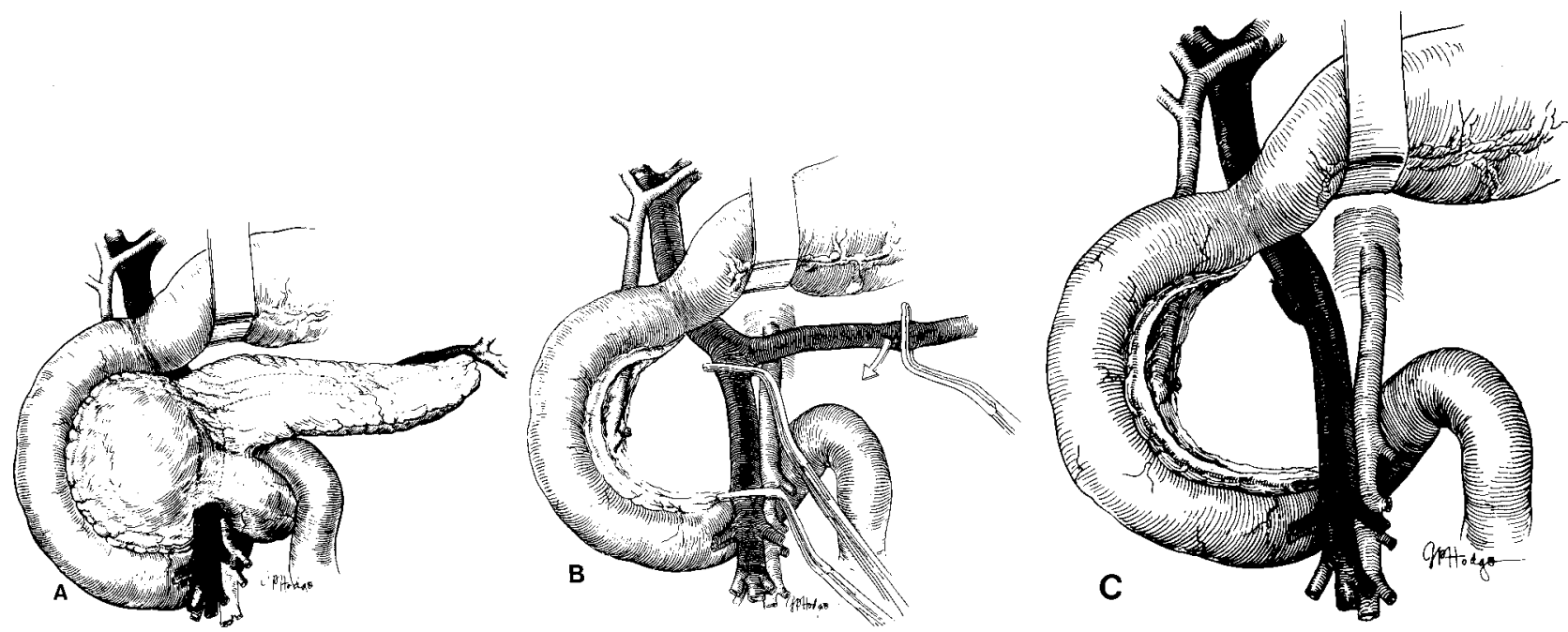

Fig. 2A. Artist's drawing of $10-\mathrm{cm}$ malignant glucagonoma arising in the pancreatic head and extending into the neck and uncinate process. The tumor encased and locally invaded the superior mesenteric vein. The patient, a 56-year-old man, had 2 small hepatic metastases and a debilitating glucagonoma syndrome. B. Artist's drawing. After a $95 \%$ pancreatectomy, sparing the common bile duct and a duodenal rim of pancreas, the superior mesenteric vein, involved by tumor and bleeding from multiple minute sites, was clamped and resected. The splenic vein was clamped and saved for vein replacement. C. Artist's drawing. The junction of the superior mesenteric and portal vein was oversewn and the distal splenic vein rotated caudally and anastomosed to the proximal stump of the superior mesenteric vein. This functioned very well. The patient had a dramatic relief of his severe skin rash within 48 hours of operation.

cess. Selective embolization may, in certain cases, prove superior to ligation. Implantable pumps for hepatic artery infusion chemotherapy are the most recently developed tools that we employ in treating functioning liver metastases. Streptozotocin combined with fluorouracil has reduced both hormone levels and tumor size. In addition to Streptozotocin and fluorouracil, dimethyltrizenoimidazole carboxamide (DTIC) has been used to treat malignant glucagonomas. Prinz and associates [23] recently reported 2 patients with the glucagonoma syndrome both of whom were treated by distal pancreatectomy with good results for more than a year. Both patients were treated for symptomatic recurrences with DTIC and had complete alleviation of their rashes along with a marked fall in glucagon levels. At least 4 other patients have been treated with DTIC with good responses and no major toxicity. The only side effect reported has been mild nausea. These authors consider DTIC the initial chemotherapeutic agent of choice in treating metastatic glucagonomas.

\section{The Verner-Morrison Syndrome}

Nearly all patients with the Verner-Morrison syndrome present with watery diarrhea which may be mild and intermittent or severe and persistent. At times the diarrhea can be life-threatening. Verner and Morrison first noted the association of severe diarrhea and islet-cell adenomas of the pancreas in
1958 [3]. Their patients also had achlorhydria and hypokalemia. In retrospect, only $50 \%$ of these patients are achlorhydric, the remainder are hypochlorhydric [1, 27]. Additional finding in some patients include episodes of flushing and hypotension. Most patients have a diabetic glucose tolerance test. Approximately one-half of patients are hypercalcemic, although they do not have primary hyperparathyroidism.

Not all patients with the watery diarrhea syndrome have islet-cell tumors. Approximately $20 \%$ of reported patients have islet-cell hyperplasia, and at least $10 \%$ have nonpancreatic tumors most commonly occurring in the adrenal gland, retroperitoneum, mediastinum, or neck $[1,3,4]$. In children, the most common cause of the syndrome is a ganglioneuroma. The majority of well-documented patients have elevated serum levels of vasoactive intestinal polypeptide (VIP). However, in some patients, only prostaglandin $\mathrm{E}_{2}\left(\mathrm{PGE}_{2}\right)$ or pancreatic polypeptide levels have been found to be elevated.

Preoperative localization in patients with VIPomas can be achieved in most cases by computerized axial tomography because nearly all symptomatic tumors are larger than $3 \mathrm{~cm}$ in diameter $[1$, 4].

The definitive treatment of the Verner-Morrison syndrome is surgical excision of the tumor or subtotal pancreatectomy $(80 \%)$ when hyperplasia or nesidioblastosis of the islet cells is the cause. Of the 
reported cases of VIPomas, 50\% have been malignant [27]. Eighty percent of these islet-cell tumors occurred in the body or tail of the pancreas. Incurable tumors should be treated by palliative resection of as much primary and secondary tumor as is feasible. Resection of benign VIPomas results in alleviation of all preoperative symptoms and metabolic abnormalities.

Preoperatively, patients with VIPomas should be carefully rehydrated and electrolyte losses, particularly potassium and magnesium, replaced. At least 7 deaths have been reported because of fluid and electrolyte abnormalities [1]. If metastatic disease precludes cure, adrenal cortical steroids should be considered. In some cases, steroids have effectively relieved the diarrhea. In patients with elevated $\mathrm{PGE}_{2}$ levels, prostaglandin inhibitors should be administered. Liver metastases that cannot be readily resected can be treated by the same techniques utilized for other functional islet-cell tumors.

\section{"Silent" and Nonfunctioning Islet-Cell Tumors}

Approximately $15 \%$ of islet-cell neoplasms produce hormones that have no apparent clinical manifestations or are not detectable by current immunoassays $[1,4]$. These tumors often may be difficult to diagnosis until metastases develop or the primary tumor becomes so large that a mass effect produces symptoms. The most frequent nonfunctioning isletcell tumor is the pancreatic polypeptideoma (PPoma). To be able to detect a tumor by its secretion(s) implies that the tumor is no longer biochemically "silent"; nonetheless, there are no distinct clinical symptoms associated with these neoplasms. Somatostatinomas have also been recently recognized by their hormonal products and by immunohistochemical stains of tumor tissue. Although a somatostatinoma syndrome has been described, many patients have had no symptoms or findings suggestive of this tumor. Both PPomas and somatostatinomas may arise in patients with the MEN I syndrome.

The general principles of managing islet-cell tumors are similar. All should be considered malignant until proven otherwise. Many will not be detected until hepatic metastases are present. Unfortunately, surgical treatment must be considered palliative, at best, in many of these patients because of the advanced stage of disease at diagnosis. In some patients surgical intervention will offer little benefit other than to establish a histologic diagnosis and stage the disease. In others, palliative resection may be of some benefit because of involvement of contiguous structures. Most patients with obvious metastases, however, will be candidates for chemotherapy with streptozotocin, 5-FU, or DTIC. Re- cently, an implantable drug delivery system for hepatic arterial infusion chemotherapy has been used to treat patients with extensive liver metastases with some success.

\section{Pancreatic Polypeptide-Producing Tumors (PPomas)}

Tumors that secrete pancreatic polypeptide cause no distinguishing clinical symptoms that can be attributed to hormone excess [28]. With the development of a suitable immunoassay capable of detecting this hormone in blood, interest in pancreatic polypeptide-secreting tumors has increased markedly [29]. Elevated levels of PP have been found in patients with the MEN I syndrome even when a discrete tumor is not present $[4,28,30]$. The apparent source appears to be dysplastic islet cells which are universally present in MEN I patients.

Until recently there has been a paucity of reports of PPomas in the literature. However, such reports are increasing in frequency since the greater availability of the immunoassay and the more frequent use of the immunohistochemistry to identify isletcell tumors excised at operation when no clinical syndrome had been identified preoperatively.

During the past 5 years (1978-1983), 8 patients with PP-producing islet-cell tumors were treated at the University of Michigan [28]. No definite endocrine syndrome could be recognized in this group of patients. Four patients presented with abdominal pain and weight loss. The principal complaint in 2 patients was diarrhea and in 2 other patients was gastrointestinal bleeding. One of the 8 patients presented with jaundice and was thought to have adenocarcinoma of the exocrine pancreas. PPomas in 2 patients were associated with the MEN I syndrome and both cases were found to be benign at operation. Of the 6 patients with sporadic PPomas, 2 were malignant as determined by diffuse hepatic metastases found at the time of operation. Both of these patients had large pancreatic islet-cell tumors. Curative resections were attempted in 6 patients. Four required pancreaticoduodenectomy and 2 underwent $80 \%$ pancreatectomy. All of the patients who underwent potentially curative resections have remained asymptomatic with blood PP levels that have returned to normal. Two patients with hepatic metastases survived for 2 and 3 years, respectively, during which time they were treated with streptozotocin.

One of the patients with a solitary, sporadic PPoma presented with abdominal pain and intermittent diarrhea. This 74-year-old woman was found to have a $9-\mathrm{cm}$ tumor in the mid-portion of the body of the pancreas and an $80 \%$ pancreatectomy was performed. The peripancreatic lymph nodes were 
found to be free of metastatic disease and there was no local invasion of the pancreas. Her diarrhea completely resolved and her blood PP levels have returned to normal and remained so during the past 2 years.

Another patient, a 20-year-old woman, became jaundiced after symptoms of right upper quadrant pain and weight loss developed. By the time she was studied, she had developed a palpable right upper quadrant mass. Selective celiac angiography demonstrated a $15-\mathrm{cm}$ tumor mass that partially occluded the superior mesenteric vein. At operation, a large mass was excised by pancreaticoduodenectomy. Although the superior mesenteric vein was compressed, it was not invaded. During a 3-year follow-up period, she has shown no evidence of metastatic disease and her PP levels have remained normal.

One of the 2 patients with metastatic disease was a 48-year-old man whose chief complaint was abdominal pain. In his case, arteriography demonstrated a vascular mass in the head of the pancreas with multiple vascular metastases in the liver, characteristic of islet-cell tumor. This patient also had portal hypertension with esophageal varices. After a histological diagnosis was established, he was treated for 2 years with a combination of 5-FU, streptozotocin, and Adriamycin ${ }^{(2)}$. During this time, he experienced intermittent anorexia, diarrhea, and abdominal pain, became progressively cachetic, and died. At autopsy, the primary PPoma measured $3 \times 4 \mathrm{~cm}$ and was located in the distal third of his pancreas. The tumor locally invaded the splenic vein and the pancreatic duct. Metastases, ranging in size from 0.5 to $6 \mathrm{~cm}$, were present throughout the liver. Additional positive lymph nodes were found in the periportal area.

Discrete PP-producing tumors of the pancreas should be treated by enucleation or curative resection whenever possible. Whenever a nonfunctional pancreatic tumor is found associated with liver metastases, it must be established whether or not it is of islet-cell origin. Malignant PPomas can be treated with streptozotocin and objective responses can be anticipated in about one-half of patients treated with this therapy [31].

Since an immunoassay for PP has become available, it is evident that many islet-cell tumors, previously considered nonfunctional, are PPomas. In our experience, more than half of the patients with these tumors have elevated basal PP levels [28]. Secretin stimulation increases PP levels in $70 \%$ of patients. In some cases, small PPomas may not be detected by a single determination of basal or secretin-stimulated PP. However, the presence of these tumors may be suspected by observing increasing serum PP levels over several months.
After resection of a tumor, elevated serum PP levels should rapidly fall to normal, provided that no occult metastases are present.

Friesen has reported that elevated PP levels in patients with the MEN I syndrome indicate multiple tumors of the pancreas. Because of the malignant potential of these islet-cell tumors, Friesen recommends exploration and possible pancreatectomy resection for MEN I patients with persistently elevated PP levels $[4,29]$. We have observed increased PP levels in $50 \%$ of our patients with carcinoid syndrome, $75 \%$ of patients with VIPomas, and $25 \%$ of patients with gastrinomas or insulinomas. Thus, before recommending blind exploration, we prefer to first localize the source of PP hypersecretion by selective portal venous sampling. An exploratory operation can then be done if a pancreatic tumor has been demonstrated by venous sampling, CT, or angiography and no metastases are seen in the liver.

Two of our patients with relatively asymptomatic PPomas were found to have angiographic evidence of liver metastases. Needle biopsy of liver confirmed the diagnosis in each case and they were treated with streptozotocin. Localization studies have helped us to determine resectability in patients with PPomas. Elevated serum PP levels occurring in patients with MEN I syndrome may reflect diffuse islet-cell dysplasia resulting in nesidioblastosis or multiple adenomatosis. Any resection short of total pancreatectomy will, therefore, not lower the PP levels in these patients. The frequency with which microscopic islet-cell tumors undergo malignant changes in MEN I patients has not been established. At present, we believe that pancreatic resections should be reserved for patients with clearly identified lesions.

PPomas may be very slow growing even when malignant. Whether surgical debulking of nonfunctioning islet-cell tumors facilitates cytotoxic chemotherapy is not known. Even when extensive metastases are present, excellent palliation can be achieved in some cases with chemotherapy. If there is no response to streptozotocin or fluorouracil, DTIC should be considered. It has been used with success in some patients with islet-cell malignancy [23].

Molecular heterogeneity is a feature of all mammalian polypeptides studied to date. The degree of heterogeneity reported for these peptides has varied but, if demonstrated, may be beneficial in establishing the diagnosis of malignancy.

Plasma from 4 patients with apparently benign PP tumors and from 2 patients with malignant PP tumors was chromatographed on a Sefadex G-100 (0.1 M formic acid) molecular sieving column [28]. Only 1 PP peak was observed in the group with 
benign tumors, but one of the patients with a malignant tumor had 2 activity peaks. Although molecular sieving chromatography may prove useful in differentiating benign from malignant PPomas, additional studies will be necessary to establish the validity of this observation.

\section{Somatostatinomas}

Somatostatinomas are rare islet-cell tumors but may be more frequent than reports would indicate [32]. Some authors have concluded that somatostatin-secreting tumors may not be "silent" but cause a syndrome consisting of adult-onset diabetes, anorexia, weight loss, distention of the gallbladder with or without cholelithiasis, and achlorhydria [33]. However, these symptoms and findings are nonspecific and relatively common in elderly patients with neoplasms of the pancreas. Furthermore, about one-third of the reported patients have not had all of the components of this "syndrome" $[1,4,30]$. It is unlikely that many new cases of somatostatinomas will be suspected and diagnosed on the basis of clinical findings alone.

Of the 11 well-documented cases, 6 patients had liver metastases at the time of diagnosis. Half of the tumors arose in the head of the pancreas. Whipple resections were done in 4 but 2 died in the early postoperative period. The primary tumors were large, ranging in size from 5 to $10 \mathrm{~cm}$. Five of these somatostatin-secreting tumors also secreted other hormones including calcitonin, $\mathrm{ACTH}$, insulin, and gastrin. Streptozotocin and 5-FU were used successfully in several patients with unresectable lesions.

Our experience with somatostatinomas has been limited. In 1 patient, a 21-year-old woman with a large $(7 \mathrm{~cm})$ "insulinoma" of the pancreatic head, elevated somatostatin and insulin levels were determined by selective pancreatic venous sampling [16]. After enucleation of the tumor, plasma levels of both hormones returned to normal. We have identified somatostatin immunohistochemically with immunoperoxidase staining in 6 of 14 islet-cell tumors excised from patients with MEN I syndrome [5]. Clinically, each of these patients presented with either a Zollinger-Ellison or hypoglycemic syndrome. One patient with ZE syndrome was treated by total gastrectomy after multiple pancreatic isletcell tumors were resected. Surprisingly, staining of metastases in a lymph node, contiguous to the primary tumor, demonstrated somatostatin but not gastrin.

The present evidence suggests that most patients with somatostatinomas will remain asymptomatic until the tumor is quite large. These tumors, even when small, should be considered malignant and excised. Large or locally invasive tumors may require extensive pancreatic resection if potentially curable. The treatment of liver metastases is similar to that described for other islet-cell carcinomas.

\section{Résumé}

Les tumeurs insulaires malignes sont rares mais elles présentent un grand interêt car si le traitement entraîne exceptionnellement leur guérison il assure une survie des malades qui en sont porteurs. Ce sont en effet des tumeurs malignes à développement lent, sensibles à l'action de l'association de la chimiothérapie et de la chirurgie. Chez certains sujets les tumeurs secrétant de l'insuline, de la gastrine, du glucagon, du V.I.P. peuvent mettre en jeu la vie du malade sous l'effet de l'hypersecrétion hormonale. Le traitement chirurgical dépend de ce fait, des caractères fonctionnels et du degré de malignité de chaque type de tumeur. En présence de lésions hypersecrétantes l'exérèse de la tumeur primitive doit être envisagée alors même que la possibilité d'obtenir une guérison définitive ne peut être escomptée. Il est aussi à noter que certaines lésions malignes ont été traitées avec succès alors que les ganglions lymphatiques correspondants étaient déjà envahis. Si l'opération est contre-indiquée en présence de métastases hépatiques la duodénopancréatectomie céphalique s'applique aux tumeurs insulaires céphaliques qu'elles s'accompagnent ou non d'un envahissement des ganglions juxta-pancréatiques. Du fait que les métastases hépatiques sont souvent multiples et qu'elles intéressent les deux lobes l'action sur le foie se limite à l'éxérèse des métastases accessibles à la résection hépatique segmentaire. Les tumeurs insulaires malignes qui ne sont pas hypersecrétantes relévent de la chimiothérapie par voie générale ou de la chimiothérapie régionale dès lors qu'elles s'accompagnent de métastases. C'est seulement lorsque ces lésions entraînent une obstruction de la voie biliaire principale ou du duodénum que la résection ou les anastomoses de dérivation sont indiquées. La chimiothérapie par voie générale ou par la voie de l'artère hépatique ou encore l'embolisation de cette dernière représentent les meilleures méthodes de traitement des métastases hépatiques. L'emploi récent de pompes à infusion de l'artère hépatique a donné des résultats intéressants chez ces malades. Les agents chimiques les plus efficaces sont la streptozotocine, le DTIC et le Fluorouracil.

\section{Resumen}

Aunque los tumores malignos de células insulares del páncreas son raros, éstos constituyen un grupo 
importante entre las neoplasias pancreáticas por cuanto el tratamiento apropiado con frecuencia resulta en una paliación efectiva a pesar de que la curación sea poco frecuente. En general estos tumores son de crecimiento lento y la combinación de la cirugía con quimioterapia puede llegar a ser beneficiosa. En algunos pacientes con tumores que hipersecretan insulina, gastrina, glucagón o VIP (polipéptido vasoactivo intestinal), los efectos hormonales del neoplasma pueden poner en peligro la vida. Por ello el tratamiento quirúrgico debe considerar tanto las caracteristicas funcionales como las de malignidad de cada tumor en particular. En muchos pacientes con neoplasmas funcionantes, el debultamiento quirúrgico del tumor primario puede estar indicado cuando la resección curativa no es realizable. Algunas neoplasias malignas pueden ser curadas mediante una resección pancreática adecuada a pesar de que los ganglios linfáticos peripancreáticos ya se hallen afectados. Aún cuando el procedimiento de Whipple no está indicado en presencia de metástasis hepáticas, esta operación puede curar tumores localizados en la cabeza del páncreas y/o en los ganglios linfáticos peripancreáticos. Debido a que las metástasis hepáticas generalmente son múlitples y afectan a ambos lóbulos, las resecciones hepáticas, diferentes de las resecciones en cuña para lesiones funcionantes localizadas en la periferie del higado no están indicadas. Los tumores malignos no funcionantes de células insulares probablemente deben ser tratadas con quimioterapia sistémica o regional cuando se encuentren en fase metastásica. Las resecciones quirúrgicas o los procedimientos derivativos infrecuentemente son de utilidad en aquellos casos en los cuales el tumor primario causa obstrucción duodenal o del conducto biliar. Los métodos de mayor efectividad en el control de las metéstasis hepáticas son los de quimioterapia sistémica y arterial hepática. Una alternativa es la embolización selectiva de la arteria hepática. Recientemente ha venido a ser utilizada una bomba implantable de infusión arterial hepfica con resultados halagadores en este grupo de pacientes. Los agentes quimioterapéuticos que han probado ser de mayor efectividad en el tratamiento de las metástasis hepáticas incluyen la estreptozotocina, la dimetiltrizenoimidazol carboxamida (DTIC) y el Fluorouracilo.

\section{References}

1. Thompson, N.W.: The surgical treatment of islet cell tumor of the pancreas. In Pancreatic Disease, T.L. Dent, editor. New York, Grune \& Stratton, 1981, pp. 461-467

2. McGavran, M.H., Unger, R.H., Recant, L., et al: A glucagon secreting alpha-cell carcinoma of the pancreas. N. Engl. J. Med. 274:1408, 1966

3. Verner, J.V., Morrison, A.B.: Islet cell tumor and a syndrome of refractory watery diarrhea and hypokalemia. Am. J. Med. 29:529, 1958

4. Friesen, S.R.: Tumors of the endocrine pancreas. N. Engl. J. Med. 306:1533, 1982

5. Thompson, N.W., Lloyd, R.V., Nishiyama, R.H., Vinik, A.I., Strodel, W.E., Allo, M.D., Eckhauser, F.E., Talpos, G., Mervak, T.: MEN I Pancreas: A histologic and immunohistochemical study. World $\mathbf{J}$. Surg. 8:561, 1984

6. Edis, A.J., Mcllrath, D.C., van Heerden, J.A., Fulton, R.E., Sheedy, II, P.F., Service, F.J., Dale, A.J.D.: Insulinoma-current diagnosis and surgical management. Curr. Prob. Surg. 13:10, 1976

7. Stefanini, P., Carbon, M., Patrassi, N., et al: Betaislet cell tumors of the pancreas: Results of a study of 1,067 cases. Surgery 75:597, 1974

8. Stefanini, P., Carboni, M., Patrassi, N., et al: Surgical treatment and prognosis of insulinoma. Clin. Gastroenterol. 3:697, 1974

9. Fajans, S.S., Vinik, A.I.: Diagnosis and treatment of "Insulinoma." In Endocrine Oncology, R. Santen, editor. (in press)

10. Bonfils, S., Landor, J.H., Mignon, M., Hervoir, P.: Results of surgical management of 92 consecutive patients with Zolinger-Ellison syndrome. Ann. Surg. 194:692, 1981

11. Deveney, C.W., Deveney, K.S., Way, L.W.: The Zollinger-Ellison syndrome 23 years later. Ann. Surg. I88:834, 1978

12. Friesen, S.R.: Treatment of the Zollinger-Ellison syndrome: A 25-year assessment. Am. J. Surg. $143: 331,1982$

13. Malagelada, J.R., Edis, A.J., Adson, M.A., van Heerden, J.A., Vay Liang, W.G.: Medical and surgical options in the management of patients with gastrinoma. Gastroenterology 84:1524, 1983

14. Zollinger, R.M., Ellison, E.C., Fabri, P.J., Johnson, J., Sparks, J., Carey, L.C.: Primary peptic ulcerations of the jejunum associated with islet cell tumors: Twenty-five years appraised. Ann. Surg. 192:422, 1980

15. Fajans, S.S., Floyd, J.C., Jr.: Diagnosis and medical management of insulinomas. Ann. Rev. Med. 30:313, 1979

16. Cho, K.J., Vinik, A.I., Thompson, N.W., Shields, J.J., Porter, D.J., Brady, T.M., Cadavid, G., Fajans, S.S.: Localization of the source of hyperinsulinism: Percutaneous transhepatic portal and pancreatic vein catheterization with hormone assay. A.J.R. 139:237, 1982

17. Dewys, W.D., Stoll, R., Au, W.Y., Salisnjak, M.M.: Effects of streptozotocin on an islet cell carcinoma with hypercalcemia. Am. J. Med. 55:671, 1973

18. Moertel, C.G., Hanley, J.A., Johnson, L.A.: Streptozotocin alone compared with streptozotocin plus fluorouracil in the treatment of advanced islet cell carcinoma. N. Engl. J. Med. 303:1190, 1980

19. Kiang, D.T., Frenning, D.H., Bauer, G.E.: Mithramycin for hypoglycemia in malignant insulinoma. N. Engl. J. Med. 296:998, 1977

20. Brennan, M.F., Jensen, R.T., Wesley, R.A., Doppman, J.L., McCarthy, D.M.: The role of surgery in 
patients with the Zollinger-Ellison syndrome managed medically. Ann. Surg. 196:239, 1982

21. Deveney, C.W., Deveney, K.E., Stark, D., Moss, A., Stein, S., Way, L.W.: Resection of gastrinomas. Ann. Surg. 198:546, 1983

22. Modlin, I.M., Brennan, M.F.: The diagnosis and management of gastrinomas. Surg. Gynecol. Obstet. 158:97, 1984

23. Prinz, R.A., Badrinath, K., Banerji, M., Sparagana, M., Dorsch, T.R., Lawrence, A.M.: Operative and chemotherapeutic management of malignant glucagon producing tumors. Surgery 90:713, 1981

24. Glowniak, J.V., Shaprio, B., Vinik, A.I., Glaser, B., Thompson, N.W., Cho, K.J.: Percutaneous transhepatic venous sampling of gastrin. N. Engl. J. Med. 307:293, 1982

25. Mallinson, C.N., Bloom, S.R., Warin, A.P., et al: A glucagonoma syndrome. Lancet $2: 1,1974$

26. Higgins, G.A., Recant, L., Fischman, A.B.: The glucagonoma syndrome. Am. J. Surg. 137:142, 1979

27. Fahrenkrug, J., Schaffalitsky, D.E., Muckadell, O.B.: Verner-Morrison syndrome and vasoactive in- testinal polypeptide (VIP). Scand. J. Gastroenterol. 53 [Supp]. 14]:57, 1979

28. Strodel, W.E., Vinik, A.I., Lloyd, R.V., et al: Pancreatic polypeptide-producing tumors: Silent lesions of the pancreas? Arch. Surg. (In press)

29. Friesen, S.R., Kimmel, J.R., Tomita, T.: Pancreatic polypeptide as a screening marker for pancreatic polypeptide apudoma in multiple endocrinopathies. Am. J. Surg. 139:61, 1979

30. Visser, P.A., Friesen, S.R.: Uncommon tumors of the APUD system. Surg. Clin. North Am. 59:143, 1979

31. Friesen, S.R., Stephens, R.L. Huard, G.S.: Effective streptozocin therapy for metastatic pancreatic polypeptide apudoma. Arch. Surg. 116:1090, 1981

32. Ganda, O.P., Weir, G.C., Soeldner, J.S., et al: "Somatostatinoma" a somatostatin-containing tumor of the endocrine pancreas. N. Engl. J. Med. 296:963, 1977

33. Krejs, G.J., Orci, L., Conlon, J., et al: Somatostatinoma syndrome: Biochemical, morphological and clinical features. N. Engl. J. Med. 301:285, 1979 